\title{
Death of the King: The Introduction of Vaccination into Nepal in 1816
}

\author{
SUSAN HEYDON * \\ School of Pharmacy, University of Otago, PO Box 56, Dunedin 9054, New Zealand
}

\begin{abstract}
This article explores the introduction of smallpox vaccination into Nepal in 1816 at the request of the Nepalese government; the king, however, was not vaccinated, contracted the disease and died. British hopes that vaccination would be extended throughout the country did not eventuate. The article examines the significance of this early appearance of vaccination in Nepal for both Nepalese and British, and relates it to the longer history of smallpox control and eventual eradication. When the Nepalese requested World Health Organization (WHO) assistance with communicable disease control in the mid-twentieth century little had changed for most Nepalese. We know about the events in 1816 through the letters of the newly imposed British Resident after Nepal's military defeat in the Anglo-Nepal War (1814-16). By also drawing on other sources and foregrounding Nepal, it becomes possible to build up a more extensive picture of smallpox in Nepal that shows not only boundaries and limits to colonial authority and influence but also how governments may adopt and use technologies on their own terms and for their own purposes. Linking 1816 to the ultimately successful global eradication programme 150 years later reminds us of the need to think longer term as to why policies and programmes may or may not work as planned.
\end{abstract}

Keywords: Nepal, Smallpox, Vaccination, Diplomacy, Global health

On 20 November 1816 King Girvana Yuddha Bikram Shah of Nepal died of smallpox. ${ }^{1}$ We know little about the circumstances surrounding his death except that Residency SurgeonMajor Daniel Wright of the Indian Medical Service also mentioned in his introduction to the History of Nepal that 'Soon after the British arrived in the country, smallpox broke out, and committed great ravages among the people', and that a genealogical history, the

* Email address for correspondence: susan.heydon@otago.ac.nz

I would like to thank the many people in Nepal who helped me in so many ways during my research. I would also like to thank the anonymous reviewers for their valuable, constructive and critical input to the development of this article.

${ }^{1}$ P.N. Shrestha, 'History of Smallpox', Journal of the Nepal Medical Association, 10, 2 (1972), 107-11. Dr Purushottam Narayan Shrestha was medical officer-in-charge of Nepal's Smallpox Eradication Project. Nepali uses the Devanagari script. Spelling of Nepali names using the Roman script varies; in this article I will mostly use the version given by the author in the specified source. 
Vansāvali, blamed the king's death on the fury of the goddess Sitala. ${ }^{2}$ Accounts written since 1816, including more recent general histories of smallpox, note only the death of the king. ${ }^{3}$ No mention is made that in the preceding months, following Nepal's military defeat in the Anglo-Nepal War (1814-16), staff of the recently established British Residency in Kathmandu obtained vaccine from India at the request of the Nepalese government and provided vaccination to the court and people of Nepal. This episode occurred more than thirty years before the more familiar reference to support for vaccination in Nepal from Prime Minister Jang Bahadur Rana, the powerful ruler of the country, who visited Britain in $1850 .{ }^{4}$ This paper will explore the significance of this early appearance of vaccination in Nepal for both Nepalese and British, and relate it to the longer history of smallpox control and eventual eradication.

The concept of technology as a 'tool' to further political aims has long been a theme - if now somewhat dated - in the literature about nineteenth-century imperial expansion, power and conquest. Smallpox was an acute, contagious, viral disease from which, almost without exception, people either died or acquired long-lasting immunity accompanied by varying degrees of disfigurement. ${ }^{5}$ Most people survived the first few days after infection to produce the characteristic rash which a few days later formed pustules. Smallpox occurred worldwide, but Nepal - like India - experienced the more virulent form of the variola virus - variola major - which had a high mortality rate. The effectiveness of vaccination had practical importance for a dreaded and horrible disease, but imperial authorities used it increasingly to demonstrate 'the growing sense of superiority of Western medicine over indigenous practice'. ${ }^{6}$ By the mid-twentieth century, national and global political environments had changed, but technological solutions, such as vaccination, remained at the centre of international responses to public health problems. ${ }^{7}$

In the early nineteenth century little could be done about most infectious diseases that people encountered, but for smallpox a technology was available. In the South Asian region smallpox-control measures predated the consolidation of European power and the introduction of vaccination. ${ }^{8}$ People widely perceived variolation (inoculation of uninfected persons with the fluid retrieved from smallpox pustules) as an effective and a familiar preventive, but by 1804 the East India Company preferred the new method

\footnotetext{
${ }^{2}$ Daniel Wright, History of Nepal (New Delhi: Rupa \& Co, 2007 [1877]), 53 and 266. While in Kathmandu Wright collected documents and took many back to Britain. The Vansāvalī, or Genealogical History of Nepal, according to the Buddhist recension, was translated by Munshi Shew Shunker Singh and Pandit Shri Gunanand. Also see: John Whelpton, 'A Reading Guide to Nepalese History', Himalaya, the Journal of the Association for Nepal and Himalayan Studies, 25, 1 (2005), Article 5.

${ }^{3}$ See, for example, Donald R. Hopkins, The Greatest Killer: Smallpox in History (Chicago and London: University of Chicago Press, 2002), 150.

${ }^{4}$ Henry Ambrose Oldfield, Sketches from Nipal (London: W.H. Allen, 1880), Vol. 1, 253-4. Oldfield was Residency Surgeon at the time.

5 Alfred W. Crosby, 'Smallpox', in Kenneth F. Kiple (ed.) The Cambridge World History of Human Disease (Cambridge: Cambridge University Press, 1993), 1008-13. [Online]. The Cambridge World History of Human Disease. Available from: Cambridge Histories Online doi:10.1017/CHOL9780521332866.190 (Accessed 22 June 2016).

${ }^{6}$ David Arnold, Science, Technology and Medicine in Colonial India (Cambridge: Cambridge University Press, 2000), 71 .

${ }^{7}$ Randall M. Packard, A History of Global Health: Interventions into the Lives of Other Peoples (Baltimore: Johns Hopkins University Press, 2016).

${ }^{8}$ Paul R. Greenough, 'Variolation and Vaccination in South Asia, c. 1700-1865: A Preliminary Note', Social Science \& Medicine, 14D (1980), 345-7.
} 
of vaccination (inoculation of uninfected persons with milder cowpox). ${ }^{9}$ Implementing vaccination, however, presented considerable challenges regarding the procurement, transportation and maintenance of safe and effective fresh lymph. ${ }^{10}$ Multiple vaccines and practices resulted, meaning that vaccination had to adapt to "existing epidemiological, social, and cultural settings in myriad ways'. ${ }^{11}$ No single or simple method existed to transfer vaccination to Nepal in 1816.

Why, however, should we be interested in smallpox in the small Himalayan kingdom of Nepal and the events of 1816, beyond what they tell us about a moment in time in a small country in a then little known part of the world? After all, the British Residency surgeons were only writing about their experiences and knowledge of the country, and Donald Hopkins, a veteran of the later and successful global smallpox-eradication programme, was highlighting the deaths of prominent people to emphasise how much smallpox has influenced the broad sweep of history. ${ }^{12}$ King Girvana was not the only monarch around the world to die from the disease. Nevertheless, can an article focusing on the death of Nepal's king from smallpox in 1816 not only tell us more about the specific events in Nepal and their context but also contribute to the wider literature and the continuing debates around the history of smallpox control and its later eradication?

Studies of small programmes are often marginalised in the literature, but Sanjoy Bhattacharya argues that they can be important not only for what they add to national histories but also for our consideration of broader narratives. He uses part of the later global eradication programme in the even smaller Himalayan kingdom of Bhutan to highlight limits to global influence. ${ }^{13}$ Nepal's dealings with the East India Company in 1816 add to our understanding of relationships and power within the colonial sphere by illustrating the agency of another government, but they also had wider ramifications for Nepal's story with smallpox. In the second volume of his comprehensive study of smallpox in India, Bhattacharya points to the importance of thinking longer term; many colonial-era structures and networks continued after 1947 and remained central to the several official efforts that culminated in eradicating smallpox from India. ${ }^{14}$ Smallpox control - and later eradication - in Nepal likewise should be thought of with a longer lens. Vaccination did not spread throughout the country as the British hoped but remained inaccessible for most people. Until the changed political and social environment of the 1950s, vaccination in Nepal challenged the more conventional narrative of linear and progressive development.

Although this article looks forward to the later eradication programme, it focuses on the historical dynamics surrounding the introduction of vaccination in Nepal in 1816.

\footnotetext{
${ }^{9}$ Ibid., 346; Niels Brimnes, 'Variolation, Vaccination and Popular Resistance in Early Colonial South India', Medical History, 48, 2 (2004), 199-228. Edward Jenner published his results using cowpox in 1798. For the worldwide dissemination of the vaccine within a few years, although not to Japan, see Ann Jannetta, The Vaccinators: Smallpox, Medical Knowledge, and the 'Opening' of Japan (Stanford, California: Stanford University Press, 2007), 34-52.

${ }^{10}$ Andrea Rusnock, 'Catching Cowpox: The Early Spread of Smallpox Vaccination, 1798-1810', Bulletin of the History of Medicine, 83 (2009), 17-36.

${ }^{11}$ Sanjoy Bhattacharya and Niels Brimnes, 'Introduction: Simultaneously Global and Local: Reassessing Smallpox Vaccination and Its Spread, 1789-1900', Bulletin of the History of Medicine, 83, 1 (2009), 1-16.

12 Hopkins, op. cit. (note 3), xiv.

13 Sanjoy Bhattacharya, 'International Health and the Limits of its Global Influence: Bhutan and the Worldwide Smallpox Eradication Programme', Medical History, 57, 4 (2013), 461-86.

14 Sanjoy Bhattacharya, Expunging Variola: The Control and Eradication of Smallpox in India 1947-77 (New Delhi: Orient Longman, 2006), 1. Randall Packard's recent overview of the history of global health also emphasises continuities. Packard, op. cit. (note 7).
} 
The structure reflects the fact that while South Asia is a familiar region for many readers of this journal, Nepal is not. The first part provides the context and history to interpret events in 1816 while the second and more narrative section considers what happened. A shorter, final section links vaccination's introduction in 1816 to the global Smallpox Eradication Programme of the 1960s. At the centre of this article are the letters from the Honourable Edward Gardner, who was appointed British representative ('Resident') at the Nepalese court in March 1816, to John Adam, then Secretary to Government in the Political Department in Fort William (Calcutta). ${ }^{15}$ A slim file in the East India Company records entitled 'Introduction of Vaccination into Nipaul' provides additional information. ${ }^{16}$ Gardner arrived in India in 1802 and by 1816 had worked in a number of civil positions; he had a flair for languages and an empathy for India. We only know about the smallpox epidemic in 1816 and the sequence of events leading up to the death of the king because one of the principal functions of a resident was to provide a regular flow of information to the Company's headquarters in India and then on to London. ${ }^{17}$ Indeed, it has been argued that this elite, male-dominated collection of knowledge was the actual basis of British domination in the South Asian region. ${ }^{18}$ Nevertheless, we can also gain insights into a Nepalese perspective and active Nepalese agency that suggests a much more limited British influence.

This article argues, therefore, that we can see boundaries and limits to colonial power through how another government operating within the colonial sphere adopted a technology on its own terms and for its own purposes. The introduction of vaccination into Nepal was not a British-initiated policy or strategy but a technology requested and a process dictated by senior officials in the Nepalese government. Although the British in India provided vaccine and vaccination as a practical and humanitarian gesture, they also used it as a diplomatic strategy to improve relations with their northern neighbour. ${ }^{19}$ Paul Greenough considers diplomacy in the much later context of Pakistan in the 1950s, but none of the other contributions in a new global history of the politics of vaccination link diplomacy to vaccination policy and practice. ${ }^{20}$ To a certain extent Nepal was embedded in the colonial project, but it was not - and did not become - part of the British Empire. ${ }^{21}$ The limited British presence in Kathmandu did not reflect the notions of control and mastery implied in 'tools' of empire but was a more sensitive and cautious handling of a situation

15 Letters to India 1816. IOR/R/5/37 and IOR/R/5/38. British Library, India Office Records (hereafter IOR) R/5 Nepal: Kathmandu Residency Records c1792-1872. Fort William was headquarters of the Bengal Presidency. Wright's spelling of Gardner as Gardiner is incorrect, op. cit. (note 2), 53. He should also not be confused with Lieutenant-Colonel Gardner - his cousin William.

${ }^{16}$ F/4 Board of Control Records 1784-1858. IOR/F/4/550/13379.

${ }^{17}$ Michael H. Fisher, Indirect Rule in India: Residents and the Residency System 1764-1857 (Delhi: Oxford University Press, 1991), 172.

18 Nicholas B. Dirks, The Hollow Crown: Ethnohistory of an Indian Kingdom (Cambridge: Cambridge University Press, 1987). For more nuanced interpretations, see C.A. Bayly, Empire \& Information: Intelligence Gathering and Social Communication in India, 1780-1870 (Cambridge: Cambridge University Press, 1996) and Tony Ballantyne, 'Colonial knowledge', in Sarah Stockwell (ed.) The British Empire: Themes and Perspectives (Malden and Oxford: Blackwell, 2008), 177-97.

${ }^{19}$ Much of Nepal shares a border with India. Endeavouring to take advantage of a political factional dispute in Nepal, the East India Company had concluded a commercial treaty with the government of Nepal in 1801. Captain William Knox was appointed Resident but the treaty proved unworkable and Knox withdrew in 1803. Only after 1816 was the relationship permanent.

${ }^{20}$ Christine Holmberg, Stuart Blume and Paul Greenough (eds), The Politics of Vaccination: A Global History (Manchester: Manchester University Press, 2017). I am grateful to Paul Greenough for letting me read a draft of his chapter.

${ }^{21}$ The country's foreign policy later became closely aligned with that of British India. 
inherent in the idea of diplomacy. ${ }^{22}$ The end of the war had not brought the secure border the British desired.

Despite the many heroic narratives of the successful global smallpox-eradication programme, the implementation of smallpox vaccination, control and the later eradication programme was in practice complex, debated and contested. ${ }^{23}$ The request and introduction of vaccination in Nepal in 1816 took place in the context of a smallpox epidemic that had spread to the capital Kathmandu. Reflecting hierarchical Nepalese society, the government request for vaccination in 1816 was made at a high level to an appropriate person, the newly imposed British Resident. In doing so, vaccination also became a political matter. Central to understanding what happened, however, was the political manoeuvring that was taking place within the Nepalese court which was the centre of political power. For much of the period after the death of King Prithvi Narayan Shah in 1775, Nepal was ruled by a regent. Favourites and rumour, death and exile thrived. Nepal-British relations became deeply entwined in the bitter factional court politics that developed, especially after the abdication of King Rana Bahadur in 1799 in favour of his infant son Girvana. ${ }^{24}$

The request for vaccination probably was not just a simple matter of acknowledging the new technology; much more was at stake for those involved at court. The British documents not only help illuminate British motivations in supporting vaccination in Nepal but also give some insight into those of senior Nepalese officials, particularly Bhimsen Thapa, who became mukhtiyar (head of administration) in $1806 .{ }^{25}$ Political survival could be a matter of life or death; when Bhimsen seized control he executed many leading figures. In the swirling court environment, concern about the health and wellbeing of the wider populace of Nepal was unlikely to be of much concern to the ruling elite. Gardner's letters do not suggest that vaccination was a divisive issue or associated with a particular faction, but the king's death led to the throne passing to his young son and enabled Bhimsen to consolidate and strengthen his position as the most dominant person in Nepalese politics. After the king's death, however, we learn that Gajraj Misra and many of the bharadari (courtiers) were keen to bring about Bhimsen's downfall. ${ }^{26}$ The experienced Misra, the royal family's guru (spiritual adviser), had been used in negotiations with the British for many years. Whether the Nepalese request for vaccination was a strategy that in

\footnotetext{
22 Daniel R. Headrick, 'The Tools of Imperialism: Technology and the Expansion of European Colonial Empires in the Nineteenth Century', Journal of Modern History, 51, 2 (1979), 231-63.

23 Sanjoy Bhattacharya, Mark Harrison and Michael Worboys, Fractured States: Smallpox, Public Health and Vaccination Policy in British India (New Delhi: Orient Longman, 2005); Brimnes, op. cit. (note 9), 199-228. For a reassessment of the introduction and spread of smallpox vaccination 1789-1900, see a special issue, edited by Bhattacharya and Brimnes, of the Bulletin of the History of Medicine, 83, 1 (2009). Harish Naraindas suggests another interpretation: in the transition from variolation to vaccination the narrative changed from a therapeutic mode and individual care to that of prophylaxis. Harish Naraindas, 'Care, Welfare, and Treason: The Advent of Vaccination in the 19th Century', Contributions to Indian Sociology 32, 1 (1998), 67-96.

${ }^{24}$ See, for example, Ludwig F. Stiller, S.J., The Rise of the House of Gorkha (Kathmandu: Educational Publishing House, 2017).

${ }^{25}$ Although the Nepalese denied the Resident direct access to the king, Gardner was able to gather information from sources within the court.

${ }^{26}$ Gardner to Adam, 17 December. IOR/R/5/38.
} 
appealing to the British might also help in territorial negotiations over the return of lands in the Tarai is not indicated. ${ }^{27}$

Although the British hoped that vaccination would spread, its introduction in Nepal proved to be limited. The challenges of geography, communication and government encountered in 1816 remained; this has relevance for broader discussions on the global history of disease and public health campaigns. ${ }^{28}$ Much that was pertinent in responding to smallpox in 1816 remained important in the wider global environment of a transformed balance of power and the emerging influence of global institutions in the early 1960s, when the Nepalese government requested assistance from the World Health Organization (WHO) with the control of communicable diseases - including smallpox. For most of Nepal's predominantly rural population, the grind of daily life had changed little. Methods of communication and infrastructure were limited, and Nepal's spectacular geography meant that it was still a country where most people had to walk everywhere. Although people knew about vaccination, accessing it remained difficult. Cases of smallpox in Nepal began to appear in international statistics in the 1960s, but these small numbers did not reflect the extent to which smallpox was still a serious and widespread health issue. Accurate reporting became a key component of smallpox control and eradication programmes, but until then little was known about smallpox or Nepal's other health problems. ${ }^{29}$ Nevertheless, by piecing together historical information about smallpox in Nepal from a variety of sources, including those of 1816, we can begin to build a more substantial and nuanced understanding of Nepal's encounter with the disease. This also enables us to question the eradication programme's dismissal of earlier information as only 'anecdotal' and the assumption built into its programme that Nepal was just a 'mountainous extension' of the Indian states of Bihar and Uttar Pradesh. ${ }^{30}$ The successes of the eradication campaign in Nepal need to be seen against the enormous challenges to be faced in implementing any programme in Nepal; many of these were the same or resonated with the situation in 1816.

\section{Reading the Archive}

Extensive historical research about smallpox in the South Asian region has been carried out, prompted 'as much by an interest in the functioning of imperialism as in the medical history of epidemic diseases'. ${ }^{31}$ Part of that functioning of empire lay in the creation of the knowledge to enable a government to do so. ${ }^{32}$ In India much of the smallpox literature

${ }^{27}$ Key officials held land in the productive Tarai. For the vital economic significance of this region to Nepal and the desire of the Governor-General to have a defined and stable boundary, see Ludwig Stiller, S.J., The Silent Cry: The People of Nepal: 1816-39 (Kathmandu: Sahayogi Prakashan, 1976). Misra was also a signatory of the Treaty of Sagauli.

28 See both ibid. and Stiller, op. cit. (note 24).

${ }^{29}$ Robert M. Worth and Narayan K. Shah, Nepal Health Survey 1965-66 (Honolulu: University of Hawaii Press, 1969), 70-1. This was the first national health survey.

${ }^{30}$ P.N. Shrestha, D.A. Robinson and J. Friedman, 'The Nepal Smallpox Eradication Programme: Description and Analysis', World Health Organization, 1977, SME/77.1, 20; F. Fenner, D.A. Henderson, I. Arita, Z. Jezek and I.D. Ladnyi, Smallpox and Its Eradication (Geneva: World Health Organization, 1988), 792.

${ }^{31}$ Greenough, op. cit. (note 8), 345. This also applies more widely within the history of medicine.

32 B.S. Cohn, Colonialism and Its Forms of Knowledge: The British in India (Princeton: Princeton University Press, 1996). Also see Ballantyne, op. cit. (note 18) and Bayly, op. cit. (note 18). Bayly concluded (p. 113) that as Britain watched Nepal 'Nepal was equally sagacious in its careful surveillance of the British and in promoting an information order which opened outward, but not inward'. Lauren Minsky, however, discusses the biases of colonial archives and popular sources - why the lower classes are unrepresented and elite versions unquestioned 
examines the later nineteenth century and is aided by an increasing amount of statistical data that became available under colonial rule at that time. ${ }^{33}$ For Nepal in 1816 such data does not exist, but it is possible to take the same Residency letters and Company file that were written, compiled and handed on to record and further colonial interests to build up an outline that foregrounds Nepal. It is clear from these documents that the Nepalese officials were directing the course of events in Nepal regarding vaccination. Gardner appears open in his opinions to Adam and does not present a particular faction's viewpoint. The letters also tell us something about smallpox beliefs and practices in Nepal at the time, although they do not mention, for example, the widespread belief in the goddess Sitala. Other sources are few, but where they do exist they can be used to supplement or corroborate the information. Together they give a better understanding not only of how Gardner was able to use vaccination as a diplomatic strategy, but also why it was a limited intervention in both the short and longer term. These factors help set the scene for the smallpox-control and eradication measures of the 1960s.

No historical research about smallpox in Nepal has been undertaken. Indeed little social historical research has been carried out. ${ }^{34}$ Accounts of the Anglo-Nepal War focus on politics and military encounters, although as little fighting occurred on Nepalese soil, the presence of an epidemic may have escaped notice. Even Ludwig Stiller's major study of the period after the war made only a brief reference to a smallpox epidemic, and none about any impact of disease on society. ${ }^{35} \mathrm{He}$ argued that although King Prithvi Narayan and his successors had unified the many 'mini-states' of the region by the late eighteenth century, 'the land, the people, the economy, and the social structures remained essentially unchanged'. ${ }^{36}$ The House of Gorkha found a way to finance the military unification and then govern the territory that 'combined the maximum centralization of authority with the minimum interference in local autonomy'. Officials compiled detailed records throughout the country for revenue-collecting purposes. ${ }^{37}$ As long as people paid taxes, life continued in the villages of Nepal much as before. ${ }^{38}$ Although elsewhere vaccination is often considered in terms of an early state-sponsored medical intervention for the wider population, the Nepalese government did not offer vaccination because it did not consider providing such a service part of its duty. ${ }^{39}$ Nor was there any public provision of education.

Given the government's lack of concern and involvement with Nepal's health problems in the early nineteenth century, official archival sources about smallpox are likely to

and so looks to other ways to investigate smallpox ideas and practices. Lauren Minsky, 'Pursuing Protection from Disease: The Making of Smallpox Prophylactic Practice in Colonial Punjab', Bulletin of the History of Medicine, 83, 1 (2009), 164-90.

${ }^{33}$ David Arnold, Colonizing the Body: State Medicine and Epidemic Disease in Nineteenth-Century India (Berkeley, Los Angeles and London: University of California Press, 1993), 117.

${ }^{34}$ Yogesh Raj and Pratyoush Onta, The State of History Education and Research in Nepal (Kathmandu: Martin Chautari, 2014).

35 Stiller, op. cit. (note 27).

36 Ibid., 12.

${ }^{37}$ Ibid:; Mahesh C. Regmi, Landownership in Nepal (Berkeley, Los Angeles and London: University of California Press, 1976).

38 Stiller, op. cit. (note 27), 32.

39 Brimnes, op. cit. (note 9), 199; Richard Burghart, 'The Formation of the Concept of Nation-State in Nepal', Journal of Asian Studies, 44, 1 (1984), 101-25. Elite families employed tutors. Wright, op. cit. (note 2), 31. State responses to vaccination were varied; in Japan, physicians who knew Western medicine became the primary disseminators. Bhattacharya and Brimnes, op. cit. (note 11). 
be limited. ${ }^{40}$ For example, only a small number of references to smallpox are obtained through keyword searching of the valuable documents of the Regmi Research Series. ${ }^{41}$ Extensive archives exist for the later nineteenth and early twentieth centuries, but much of the content has yet to be examined. ${ }^{42}$ Current research reveals that much information from documents about the early hospitals established from the late nineteenth century has a political and economic rather than social focus as the ruling Rana autocracy, while wanting to establish a 'modern' health system, had 'no intention of diverting the monetary flows away from the state coffers' ${ }^{43}$ Additionally, little research has been done into the development or practice of the different medical or healing systems that have been and continue to be part of the landscape of a plural health environment. ${ }^{44}$

In interpreting the 1816 documents a number of themes emerge. Nepal's geography has had a profound influence on its history. ${ }^{45}$ Rectangular in shape and landlocked, Nepal is divided broadly into three areas: the lower and flatter Tarai to the south, the middle hills and the mountains of the Himalaya near the northern border. Major river systems further divide the land; and heavy summer monsoon rains often wash out tracks and bridges. On its southern, eastern and western borders lay the territories of the British or their dependents; to the north China. Many routes through Nepal were north-south in orientation following the contours of the land. Oldfield listed six of the most important passes to the north that crossed the mountains into Tibet and were used as trade routes by pilgrims and in 1792 by the Chinese invading army. ${ }^{46}$ Within Nepal in the early nineteenth century, the hulak sewa, which used human porters, carried government mail and goods across the mountains in an east-west direction from Kathmandu. ${ }^{47}$

Although often perilously narrow or steep, such tracks and internal mobility facilitated the spread of disease. Nepal's climate ranges from the heat of the jungle and plains to the cold Himalayan environment of the highest mountains in the world, but the smallpox virus could survive throughout the country. In 1816 the epidemic spread internally from the west. Smallpox was also prevalent in the countries surrounding Nepal. To the north, Oldfield noted the seasonal movement of Tibetans during the cold months, from November to March, to milder Nepal. ${ }^{48}$ British historical descriptions of diseases in Nepal noted the presence of smallpox but focused on 'fever' and particularly the dangers, especially in the summer, of malaria in many of the valleys and the Tarai. ${ }^{49}$ This British concern

\footnotetext{
${ }^{40}$ While leading families often had their own 'baids, or medical men', no services existed for the poorer classes. Wright, op. cit. (note 2), 44.

41 The over-four-thousand pages of the Regmi Research Series have been digitised and can be accessed through the Digital Himalaya Project (http://www.digitalhimalaya.com/) and searched through http://ebooks.library.corn ell.edu/r/regmi/.

42 That the situation was changing is evident after the great earthquake of 1934, when concern for the threat of epidemics led to vaccine being imported from other countries. Brahma Shumsher Jung Bahadur Rana, The Great Earthquake in Nepal (1934 A.D.), trans. by Kesar Lall, (Kathmandu: Ratna Pustak Bandar, 2013). First published in Nepali in 1934, the author was Director of Hospital Management; but as he was also a member of the elite ruling Ranas, Yogesh Raj urges caution. Yogesh Raj, 'Management of the Relief and Reconstruction after the Great Earthquake of 1934', Studies in Nepali History and Society, 20, 2 (2015), 375-422.

43 Yogesh Raj, Deepak Aryal and Shamik Mishra, 'Documents Related to the Early Hospitals in Nepal', Studies in Nepali History and Society, 21, 2 (2016), 347-400.

${ }^{44}$ Ibid.

45 Stiller, op. cit. (note 24).

46 Oldfield, op. cit. (note 4), 8-11.

47 Stiller, op. cit. (note 27), 34-8. The service reached both eastern and western borders

48 Oldfield, op. cit. (note 4), 11.

${ }^{49}$ Oldfield, op. cit. (note 4), 47.
} 
had logistical implications for transporting and maintaining a supply of vaccine in July during the 1816 epidemic. In describing the journey to Kathmandu, Wright noted that the important village of Hetowra was almost deserted from April to November because of a fever that was 'deadly to all except the natives [the Tharu] of the Terai'. During 'the cold weather almost all the imports for the supply of Nepāl pass through Hetowra, and, in consequence, a Nepalese officer and guard of soldiers are stationed there, who however retire to the hills as soon as the hot weather sets in'. ${ }^{50}$

Although the British actively sought information about Nepal, much less was available to Gardner in 1816 than to Oldfield or Wright later in the century. In late 1792 the British Government in India received a request from Nepal for military aid against the Chinese, which it declined. It sent Captain William Kirkpatrick in 1793 to mediate, but by the time he arrived a treaty had been concluded. Kirkpatrick spent seven weeks in Nepal and wrote an account with the aim of the 'advancement of geographical knowledge'; Nepal was 'Terra Incognita' to the British outsiders. ${ }^{51}$ Unfortunately, Kirkpatrick did not discuss smallpox. He did, however, list it in his vocabulary that he compiled for two of the main vernacular languages, spoken by the 'Purbutti' (the 'peasantry of the mountainous country') and the Newar (the main indigenous people of the Kathmandu Valley area). ${ }^{52}$ Each vocabulary had a word for smallpox. ${ }^{53}$ Other words about ill health were more symptomatic or general, such as 'a cough' or 'a fever'. ${ }^{54}$ Smallpox, therefore, was a specific and identifiable disease to the Nepalese.

By drawing on various sources it is possible to gain some idea about the epidemiology of smallpox in Nepal. Smallpox was more common 'in the crowded town than in the villages'. ${ }^{55}$ Estimates of the total population ranged between four and five million. ${ }^{56}$ Its density varied throughout the country, but the Kathmandu Valley area was the most densely populated, which aided the spread of a range of infectious illnesses. Kirkpatrick described the streets of Kathmandu as 'excessively narrow, and nearly as filthy as those of Benares'. ${ }^{57}$ Most other towns were small. In 1816 smallpox was already present in the west before reaching Kathmandu, but more recent references suggest that not all parts of the country suffered from smallpox. ${ }^{58}$ Smallpox was most contagious during the first week of illness, but by this time a person was ill and generally at home. The disease, having travelled along a communication route, then tended to spread within families and households. ${ }^{59}$

Gardner's letters indicated that all classes, whether rich or poor, suffered with smallpox. The death of the king in 1816 was not an isolated event in Nepal's history - although it was the last time a king of Nepal died from the disease. In 1715 King Mahindra Malla

\footnotetext{
${ }^{50}$ Wright, op. cit. (note 2), 3.

${ }^{51}$ Colonel Kirkpatrick, An Account of the Kingdom of Nepaul being the substance of observations made during a Mission to that country in the year 1793 (New Delhi: Manjusri Publishing House, 1969), 4 and 1.

52 Ibid., 101. The Kathmandu Valley was often referred to as 'Nepaul proper'.

53 Bephen (Purbutti), Tou Ryê (Newar). Ibid., 238.

54 Ibid.

55 Shrestha, op. cit. (note 1), 108.

${ }^{56}$ ESCAP, Population of Nepal. Country Monograph Series No. 6 (Bangkok: United Nations, 1980), 11. This report draws on Nepali-language documents. Early British enumerations of the population of Nepal are considered unreliable.

${ }^{57}$ Kirkpatrick, op. cit. (note 51), 160.

58 Worth and Shah, op. cit. (note 29).

59 World Health Organization, 'Frequently asked questions and answers on smallpox'. http://www.who.int/csr/ disease/smallpox/faq/en/ (Accessed 18 January 2017).
} 
of Lalitpur died of smallpox. ${ }^{60}$ Deaths at this time within the upper echelons of society suggest that smallpox affected wider Nepalese society, but sources are even more limited than a century later. ${ }^{61}$ A royal order in 1805 recorded an outbreak of smallpox among the jhara (bonded) labourers at Chisapani in the hills around the 'valley of Nipal' ${ }^{62}$ Chisapani was situated on the hulak sewa route and a communication point. In 1856 Prime Minister Jang Bahadur instigated the first population census of Nepal. Data collected for urban and rural Kathmandu, Patan and Bhadgaun referred to houses depopulated as a result of epidemics. Urban Patan had 22000 'old Newar houses', but this total was 'exclusive of 2,000 houses depopulated as a result of a pox epidemic', and urban Bhadgaun had 11 500 'old Newar houses', a total 'exclusive of 500 houses depopulated as a result of a smallpox epidemic'. ${ }^{63}$ Such information illustrates that detailed statistical data could be gathered when wanted. Depopulation also occurred in rural areas. Indian explorer Hari Ram travelled through the Mt Everest region in 1885 and secretly gathered information for the Survey of India. His report noted that after 'an outbreak of virulent small-pox having been brought over from the east - which carried off a large number of the inhabitants of Khumbu - the road [to the Arunkosi] was closed and it is now completely lost' ${ }^{64}$

Nepal is ethnically diverse with multiple cultural backgrounds and with each of the different geographic areas having its own ethnic and cultural composition. ${ }^{65}$ First-hand knowledge and experience of Nepal as a whole was beyond Gardner since, although not part of the Treaty of Sagauli conditions, the Nepalese in practice confined Europeans to the Kathmandu Valley. Kirkpatrick's information was limited and at times inaccurate. He found the Newar to be 'interesting people' and hoped at a later date to provide a fuller account. ${ }^{66}$ Of people to the east 'we know at this time little more than the names' ${ }^{67}$ He wrote of Brahmans in the army, but in contrast to the situation in northern India, Brahmans in Nepal were not normally recruited. ${ }^{68}$ By the early nineteenth century, the political changes of the new state had seen Kathmandu become the capital, with 'a new elite structure' created as a large number of high-caste families from Gorkha and other absorbed principalities moved to the new centre of power. ${ }^{69}$

Although Gardner's focus was on the beneficial value of vaccination, the letters reveal some of the ideas about smallpox circulating among the court. It was well known that surviving an attack of smallpox conferred an expected lifelong immunity. Senior Nepalese officials stated their concern that the king - unlike his junior queen - had not had the disease during his childhood. Part of the landscape of responses to the disease at this time was variolation, which, if successful, people considered achieved the desired immunity.

\footnotetext{
${ }^{60}$ Baburam Acharya, 'King Prithvi Narayan Shah'. Regmi Research Series (Kathmandu), 8, 8 (1976), 154.

61 See Minsky, op. cit. (note 32).

62 Smallpox Epidemic in Chisapani, royal order to Subedar Antya Khawzas and Subedar Niranja. Regmi Research Series (Kathmandu), 20, 11 (1988), 160. In the Nepali calendar this is shown as 1862.

63 Population of Kathmandu Valley, 1856. Regmi Research Series (Kathmandu), 2, 5 (1970), 117-8. Today the city is known as Bhaktapur.

${ }^{64}$ Report on Routes by Explorer Hari Ram, Records of the Survey of India 8 (Dehra Dun: Survey of India, 1915), part 2, 386.

65 Shrestha, Robinson and Friedman, op. cit. (note 30), 10.

${ }^{66}$ After unification of Nepal, the Newar were a conquered people.

67 This limited knowledge would change. For the scholarly contribution of Brian Houghton Hodgson, see David M. Waterhouse (ed.), The Origins of Himalayan Studies: Brian Houghton Hodgson in Nepal and Darjeeling 1820-58 (London and New York: RoutledgeCurzon, 2004).

68 Kirkpatrick, op. cit. (note 51), 183-4. I would like to thank one of my anonymous reviewers for this comment.

${ }^{69}$ K.L. Pradhan, Brian Hodgson at the Kathmandu Residency, 1825-43 (Delhi: Spectrum Publications, 2001 ), 8.
} 
Although not giving a source or any other information, Shrestha has suggested that variolation was well known during the reign of King Prithvi Narayan. ${ }^{70}$ Oldfield in his outline of Newar castes lists the kaussa, who were 'inoculators of smallpox'. ${ }^{71}$ They were regarded as inferior in status to some Buddhists, but were still a clean caste. After the introduction of vaccination, variolation continued to be used at the highest level. In 1830 'Dhirja Vaidya, who had conducted variolation on a royal prince' was granted exemption from various forced-labour and tax obligations. ${ }^{72}$ This was significant given the extreme burden under which most people lived.

Gardner's letters suggest that the Nepalese did not reject vaccination in itself, as does the comment from Assistant Surgeon Charles Everest to Superintending Surgeon Gillman in Patna that 'These people swarm around me in such numbers that I have little time to spare' ${ }^{73}$ On a number of occasions, however, the letters refer to the time of year and its suitability for vaccination. Most infectious diseases show characteristic seasonal variations in incidence; smallpox in temperate climates was a winter/spring disease, like measles and chickenpox. Lauren Minsky has noted that because the side effects of vaccination affected people's ability to work, parents from the agrarian lower classes in colonial Punjab preferred to have their children vaccinated before the spring harvest and only when smallpox was present. ${ }^{74}$ When Everest offered vaccination in the Kathmandu Valley area, many people from different social and ethnic groups accepted. The month was September and the busy Newar rice-planting season had finished. Later Oldfield wrote of Jang Bahadur's 'great faith' in vaccination, and that he 'has had all his children, most of his brothers' and the children of the royal family vaccinated'. ${ }^{75}$ Oldfield made no suggestion, however, that vaccination was available in other parts of Nepal or for other groups. ${ }^{76}$ Later stories from the 1950s and 1960s of people who had smallpox or cared for family members indicate that people with the disease were looked after in the family home with offerings made to the appropriate deity. ${ }^{77}$ They might consult a healer in severe cases.

The Hindu goddess Sitala held a central place in many people's beliefs and practices around smallpox. In the Kathmandu Valley, most of the indigenous Newar population practise a mixture of Hinduism and Buddhism. The important Buddhist temple complex of Swayambhunath contains a square, two-storey temple devoted to the worship of Sitala. King Rana Bahadur ordered its desecration after his Brahman mistress - Girvana's mother - committed suicide when she lost her beauty through disfigurement by the scars from an attack of smallpox, ${ }^{78}$ and he forbade worship of the goddess. After his abdication, the temple was purified and reopened. His grief and actions illustrate royal power, but

\footnotetext{
${ }^{70}$ Shrestha, op. cit. (note 1), 109.

71 Oldfield, op. cit. (note 4), 186. The Newar had a well-established caste system.

72 Tax Exemption (Ashadh Badi 9, 1887) [1830]. Regmi Research Series (Kathmandu), 7, 2 (1975), 26. The name Vaidya suggests he was a practitioner of Ayurvedic medicine.

7321 September. IOR/F/4/550/13379. Later accounts suggest that some cultural resistance to vaccination existed among some groups, notably the Newar.

${ }^{74}$ Minsky, op. cit. (note 32), 185.

75 Oldfield, op. cit. (note 4), 253. Such influence probably reflected Jang Bahadur's powerful position - more powerful than that of Bhimsen Thapa in 1816.

${ }^{76}$ No mention is made of the vaccination status of Gurkha troops recruited and employed by the East India Company.

${ }^{77}$ Interviews undertaken by the author in the Newar town of Kirtipur, May 2017.

78 Oldfield, op. cit. (note 4), 285-6. Brahman astrologers, reflecting many people's unhappiness with the socially unacceptable relationship between Girvana's parents, spread a rumour that their child would die of smallpox. Chittaranjan Nepali, 'Reign and Abdication of King Rana Bahadur Shah'. Regmi Research Series (Kathmandu), 3, 1 (1971), 8 .
} 
the temple's reopening illustrates the ongoing widespread influence of Sitala. ${ }^{79}$ Belief in Sitala and vaccination, however, were not mutually exclusive. Minsky discusses how people actively sought safe and effective protection from smallpox and says that it is a mistake to focus only on the 'religiosity' ${ }^{80}$ This point is important because in later accounts, including the official history of the eradication programme, non-acceptance became equated with the idea of 'cultural resistance' and was particularly associated with belief in and worship of the goddess Sitala rather than any other beliefs or concerns. Cultural resistance was often associated with 'backward' and uneducated people. Oral sources and WHO field reports from the Kathmandu Valley in the early 1960s suggest that many reasons contributed to non-acceptance, such as not realising that re-vaccination for smallpox was necessary or that the working hours of the vaccinators were the same as those of the people. ${ }^{81}$

Gardner's letters and the East India Company file, together with additional sources to support and supplement the reading of the colonial archive, can be used, therefore, not only to tell us about their content from a British perspective but to provide information that foregrounds Nepal's encounter with smallpox. They may only be limited glimpses and about only a few parts of Nepal, but they are important when looking beyond the events of 1816 to smallpox in the long period of authoritarian rule under the Rana system of hereditary prime ministers. This period would bring little change for most Nepalese, although it made Nepal a stable neighbour for the British in India until India gained independence in $1947 .{ }^{82}$

\section{Introducing Vaccination into Nepal}

Michael Fisher in his study of British indirect rule in India uses Nepal as a case study of one 'extreme' within the residency system, in which Nepal not only initially rejected the influence of the East India Company but also continued to do so. ${ }^{83}$ By way of posting a Resident in different states, the British developed techniques of indirect rule that they used to expand their influence and control throughout the region in areas where, for a variety of reasons, they did not rule directly. Nepal became part of the residency system but managed to remain outside indirect rule. The Residency in the capital Kathmandu did not become the means for British control of Nepal. ${ }^{84}$

Nepal emerged as a state in its present form in the late eighteenth century when, as John Whelpton succinctly writes, 'the small hill kingdom of Gorkha, some eighty miles west of Kathmandu, brought much of the Himalayan foothills and an adjoining strip of the North Indian plain under its control, and the kingdom's Shah dynasty moved its court to the Kathmandu Valley'. ${ }^{85}$ King Prithvi Narayan was not alone in such endeavours but was

\footnotetext{
79 This supports the view that Sitala was more than a village/folk deity. Fabrizio M. Ferrari, Religion, Devotion and Medicine in North India: The Healing Power of Sítala (London: Bloomsbury, 2015), xx.

${ }^{80}$ Minsky, op. cit. (note 32), 171.

${ }^{81}$ Field Visit Report on Smallpox Control Pilot Project, Nepal WHO Project: Nepal 9 by Dr A. Zahra, Regional Adviser in Communicable Diseases, 23-6 May 1962. SEA/Smallpox/4. 10 August 1962.

82 Vaccination continued to be offered at the British Residency.

${ }^{83}$ Fisher, op. cit. (note 17), 414-22. The origins of the residency system in India lay in the rapid expansion of the Company's activities in India with the first resident appointed in 1764.

${ }^{84}$ After the fall of Bhimsen Thapa in 1837 political factions divided the Nepal court even more than usual, enabling the Resident Brian Hodgson to acquire a greater influence, albeit without the full support of the Company. Hodgson was recalled in 1843. In a treaty in 1923 Britain formally recognised Nepal's independence. 85 John Whelpton, A History of Nepal (Cambridge: Cambridge University Press, 2005), 1.
} 
part of a pattern of state building and expansion across a wide region of Asia. New regional powers were emerging. ${ }^{86}$ Sandwiched between the East India Company to the south and China to the north, Nepal's traditional foreign policy was to balance the influence of each. In fact, the Nepalese and British were on a 'collision course' over access to trade routes through the Himalaya to Tibet. ${ }^{87}$ The abdication of King Rana Bahadur in 1799, which Stiller called 'irresponsible', was pivotal to the deep entwining of Nepal-British relations with factional court politics and, thereby, the weakening of the unity of the new state. ${ }^{88}$

At first the British regarded their war with Nepal in 1814 'as a mere affair with a troublesome Raja of the frontier', and were surprised by their early setbacks. ${ }^{89}$ Despite Nepal's eventual military defeat, the end of Nepal's territorial expansion and the imposition of a British Resident, the East India Company did not proceed to establish indirect rule. This new arrangement, despite some fears in Nepal that it might, also did not change the relationship between Nepal and China. ${ }^{90}$ The Nepalese government continued to send independent missions throughout the region. Nepal, like Burma, Assam and Afghanistan, where the Company made considerable efforts at control, was situated in the mountains and was on the edge of the Indian cultural world, but Fisher considered Nepal to be different. The strategies of the court to isolate and so limit the influence of the Resident, and to maintain its links with outside powers, were highly significant in hindering Company control. ${ }^{91}$ Both were evident to the first permanent Resident after his arrival. ${ }^{92}$ The Residency was located deliberately outside the city, and Gardner became an observer rather than a participant, pursuing a policy of non-interference in Nepalese affairs. He could do little else.

The appointment of a permanent British representative was part of the terms of the Treaty of Sagauli imposed in 1816 after Nepal's defeat and was highly unpopular with the Nepalese. Despite earlier efforts at information gathering, lack of intelligence severely hampered British military operations during the war. ${ }^{93}$ In an official minute the GovernorGeneral of India, Lord Moira, explained clearly the British position.

The nature of the differences which have subsisted between two Governments, the result of the late war so fatal to the interests and greatness of the Goorka power, and the novelty of our relations with the government, together with our little experience of their manners, customs, and character, will render the situation of Resident at Catmandoo, for a time at least, one of considerable importance and delicacy, and my attention has been sedulously directed to the selection of an officer qualified to do it justice, by talents, judgment, temper and sagacity, combined, as far as might be attainable, with a knowledge of the people. ${ }^{94}$

${ }^{86}$ Ibid., 37. See also: Bernardo A. Michael, Statemaking and Territory in South Asia: Lessons from the AngloGorkha War (1814-16) (London and New York: Anthem Press, 2012).

${ }^{87}$ Stiller, op. cit. (note 24), 330-2.

88 Ibid., 319.

${ }^{89}$ H.T. Prinsep, History of the Political and Military Transactions in India during the Administration of the Marquess of Hastings, 1813-23 (London, 1825), 1, 133. Quoted in Sir Penderel Moon, The British Conquest and Dominion of India (London: Duckworth, 1990), 377.

${ }^{90}$ Stiller, op. cit. (note 27), 100.

${ }^{91}$ Fisher, op. cit. (note 17), 415.

92 See note 19.

93 Bayly, op. cit. (note 18), 108-13.

9416 March 1816, Enclosure No. 14 Governor-General's Minute, Papers respecting the Nepaul War, 964. East India Company, Papers regarding the Administration of the Marquis of Hastings in India (London: J.L. Cox, 1824), Papers respecting the Nepaul War, 972. In these letters he is referred to as Lord Moira (the Earl of Moira), but in December 1816 he became the first Marquis of Hastings, by which name he is better known. 
Gardner arrived in Kathmandu in July. Over the next six months, the government of Nepal and the Governor-General, through the channel of the Resident, commenced negotiations which included the return of parts of the Tarai to Nepal. In a private letter to Secretary John Adam, however, Gardner wrote that the senior Nepalese officials he was meeting with had requested the 'introduction of Vaccination'. ${ }^{95}$ Their concern was that smallpox was 'raging' in the country 'and the Raja [king] has never had the disease'. The presence of a major epidemic at this time of year is somewhat surprising as the prevalence of smallpox was normally lower in the hotter, wet summer season (June to September) than in other months. ${ }^{96}$ In India the British had considered the disease too dangerous to ignore; after the procedure of vaccination first arrived in 1802 Europeans soon adopted the new method. ${ }^{97}$ They had also thought that the local population would likewise be enthusiastic about the new technology. This was not to be, although practice and attitudes varied in different parts of India. ${ }^{98}$ In contrast to the more cautious approach in Nepal, the Governor of Bombay directed the Resident at Poona to provide vaccination for the people. ${ }^{99}$ Gardner personally was enthusiastic about vaccination, although it is not mentioned if he had been vaccinated. He would have been aware of its mixed reception among the local population; in the Bengal Presidency, which administered the Kathmandu Residency, vaccination numbers were low. ${ }^{100}$

Gardner clearly saw the political opportunity that was being presented. 'It would not only be an act of humanity to introduce the Vaccination, but be a desirable object, perhaps to have the Raja and the Officers of the Court inoculated by us. ${ }^{101} \mathrm{He}$ asked the Residency Surgeon, Everest, to write 'to Patna' to obtain some 'Matter' (vaccine). ${ }^{102}$ Whether he would have initiated an offer of vaccination we do not know. Nevertheless, Gardner was unsure if Everest would be successful and so told Adam he was writing to him privately because it was important that he obtain 'the necessary quantity and of a wholesome quality from Calcutta, or wherever it can best be procured'. ${ }^{103}$ As well as the diplomatic opportunity presented by the Nepalese request, Gardner was keenly aware of the pitfalls if the initiative went wrong. Gardner planned for Everest to vaccinate some children to demonstrate the effectiveness of vaccination, hoping that the king would also agree to being vaccinated. Aware of the diplomatic significance for Gardner in his developing relations with the Nepalese officials, Adam wrote to the Bengal Presidency's Medical Board and urged that a supply be sent 'without delay'. ${ }^{104}$ The Board assured Adam that supplies would be sent from the Presidency and the Division of Dinapore 'until they have received intimation that vaccination has been established at that Capital'. ${ }^{105}$

9517 July. IOR/F/4/550/13379.

96 P.N. Shrestha, 'Smallpox Eradication in Nepal', 9. WHO/SE/78.107.

97 Brimnes, op. cit. (note 9).

98 Ibid. In Britain opposition to vaccination occurred from the beginning.

${ }^{99}$ Fisher, op. cit. (note 17), 207.

100 Arnold, op. cit. (note 33), 134.

101 Gardner to Adam, 17 July. IOR/F/4/550/13379. Gardner often used the terms 'vaccination' and 'inoculation' interchangeably, rather than using 'inoculation' to refer to 'variolation'. The overlap in form and method between variolation with variola crusts and vaccination with vaccinia crusts also helps explain Gardner's use of the term 'inoculation' to refer to both variolation and vaccination.

102 Near Patna, in Bihar state, was the military station of Dinapore - the closest senior British station to Kathmandu. Patna was a staging post for communications with Calcutta. Waterhouse, op. cit. (note 67), 3. Although Gardner refers to Everest as Surgeon, his rank was Assistant Surgeon.

103 Gardner to Adam, 17 July. IOR/F/4/550/13379.

104 Adam to Peter Cochrane, President, and Members of the Medical Board, 3 August. IOR/F/4/550/13379.

105 Robert Leny to Adam, 7 August. IOR/F/4/550/13379. 
Gardner's letter of 14 September confirmed that 'several packets of the vaccine matter' had arrived. ${ }^{106}$

The correspondence demonstrated the Resident's awareness of two aspects of smallpox vaccination that were key to the success of this diplomatic strategy: a sufficient and reliable supply of vaccine, and vaccine of appropriate quality. In the early nineteenth century the viability and efficacy of the vaccine was uncertain, a problem heightened by the effects of distance and travel time. ${ }^{107}$ The dates of the two letters of 30 July and 14 September 1816 suggest that the journey took several weeks. Arm-to-arm vaccination using children was widely considered to be the most effective way of maintaining a source of the virus, but Gardner's letter referred to 'packets'. Although the wet and humid monsoon weather and the dangers of malaria in the Tarai were conditions found elsewhere in India and did not prevent the use of human vaccinifers, it is unlikely that the human-to-human transmission method would have been used initially to get the vaccine to Nepal because, as mentioned earlier, the route was little used at this time of year. The contents of the packets were most likely preserved vaccinia crusts.

Vaccination began on 13 September at Banepa in the southeast of the Kathmandu Valley. Gardner's letter to the Medical Board stated that Everest 'is already attended by numerous patients - I trust his exertions for its introduction may be successful for which I of course naturally feel considerable degree of interest' ${ }^{108}$ Gardner was keeping a close watch on what was happening. No accurate information, however, is available about numbers of people vaccinated, but Gardner requested that

In the mean time I take the liberty of suggesting that he be more frequently \& regularly supplied . . until he can report that the disease has been taken as the present enquiries and anxiety felt by all classes to benefit by it would render a failure in his endeavours for its introduction peculiarly unfortunate and embarrassing. ${ }^{109}$

An assured supply, therefore, was both medically and diplomatically necessary.

Gardner's letters at this time conveyed the optimism that many felt about vaccination and the superiority of 'Western' 'scientific' medicine. They indicate that he was keen to introduce what he referred to as the 'benefit' of vaccination, initially throughout the Valley and then to other parts of the country. ${ }^{110}$ Gardner does not express any concern for himself or the small number of staff and military escort. While the families of the immediate members of the Court and of the Principal Chiefs and People of the Country' were vaccinated, the king and his immediate family were said to be showing 'reluctance'. He was not said to be opposed to vaccination, and 'reluctance' is not necessarily refusal. ${ }^{11}$ The content of vaccinia crusts was known to be unreliable and some people still considered these to be inferior to variolation in the production of effective immunity against smallpox. Gardner had already written to Adam in a private letter of wanting to demonstrate vaccination's efficacy. ${ }^{112}$

Smallpox was not mentioned in any October letters, but early in November Gardner wrote that he had received a proposal in person from Bhimsen 'for the immediate

\footnotetext{
106 Gardner to Leny, 14 September. Misc letters sent June 1816-March 1817. IOR/R/5/112.

107 Crosby, op. cit. (note 5), 1012.

10814 September. IOR/R/5/112. Distant Banepa was Bhimsen Thapa's choice.

109 Ibid.

${ }^{110}$ Gardner to Adam, 25 September. IOR/R/5/37.

111 Today we talk about 'vaccine hesitancy'.

112 Gardner to Adam, 17 July. IOR/F/4/550/13379.
} 
vaccination of the Raja and his family'. ${ }^{113}$ Gardner continued that 'In concurring with this proposition however it was deemed most prudent to postpone the operation until the disease could be taken from a living subject and Mr Everest accordingly proceeded to inoculate several children \& people ... with the view of obtaining it'. We are not told why such concerns appeared only in connection with the royal family. While this was the most effective method in the early nineteenth century, Bhimsen's actual reasoning is unclear. Although King Girvana was no longer a minor, Gardner was unable to communicate directly with him and did not know his personal views or who was making decisions. It may, already, have been too late for a vaccination to prevent the disease, but this delay had unfortunate consequences as 'I regret to say that the natural smallpox was taken by the Raja's immediate family. His youngest son a child under two years of age I am sorry to add died this morning of that distemper and his eldest \& only remaining male child has also taken the disease'. ${ }^{114}$ Gardner also understood that the king had been separated from his family but feared he might still contract the disease. He urged again that they should not wait but 'submit without delay to vaccination' using the material held by Everest, but suggested repeating the procedure 'from the first living subject who may be in a fit state to communicate it'. 115

Gardner hoped that 'the Durbar [court] will see the expediency of this advice \& take advantage of it', but this was not to be. ${ }^{116}$ On 18 November he received a visit - not from Bhimsen Thapa but from Gajraj Misra - 'to communicate to me that the Raja had unfortunately taken the smallpox which I lose no time in reporting to you for the information of His Excellency the Governor General in Council'. ${ }^{117}$ It is possible that factional politics, with both men trying to control access to the king and decisions over his health treatment, may have played a part in the king not receiving vaccination in time. Gardner continued that 'the Raja is represented to be doing well and although I was only informed of the circumstances this morning I suspect it to have been discussed for these two days past'. He added that the 'circumstances of the Raja's infection is much to be regretted however, the more particularly as many opportunities have unaccountably been neglected for him receiving the vaccination'.

Gardner also reflected on the situation from the diplomatic perspective, which was not surprising given the territorial negotiations that were taking place at the same time and also British concerns about Nepal's relationship with China.

It is to be hoped that he may recover but should it happen otherwise I think it would lead to no very serious consequences to this state or any particular changes beyond the requisite formation of a Regency in the name of the young prince who with the Raja's daughter had taken the disease and is said to have completely recovered from its effects. ${ }^{118}$

The British perhaps hoped this gave them an opportunity for more influence, although Fisher notes that the greatest period of instability in relations between indigenous rulers and the residents was around the time of succession. ${ }^{119}$ Gardner's comments later in the letter about a mission from Lhasa reinforce the view of his outsider status in Nepal.

\footnotetext{
113 Gardner to Adam, 2 November. IOR/R/5/38.

114 Ibid.

115 Ibid. At this time the need for revaccination, which became part of the later protocols, was not recognised.

116 Ibid.

117 Gardner to Adam. IOR/R/5/38.

118 Ibid. The young prince was three years old.

${ }^{119}$ Fisher, op. cit. (note 17), 65.
} 
The mission envoys were presented to the king, although Gardner surmised that 'his illness I conclude did not admit of the transaction of any particular business'. ${ }^{120}$

Two days later, Gardner conveyed the news of the king's death from smallpox. He had caught the disease 'in the natural way and which had proved fatal'. ${ }^{121}$ Gardner reported that 'Alarming symptoms it seems made their appearances during the night which continuing unabated, the Raja was according to the usual custom in this country conveyed early in the morning to the temple at Pusputhnath, where he breathed his last about 11 o'clock am'. As was Hindu custom, preparations were underway quickly for his funeral. The king's death was not the last in the family as his senior queen, Siddhi Rajya Laxmi, who was mother of the new king, Rajendra Bikram, became a sati (self-immolation). ${ }^{122}$ Gardner later reported that the junior queen, Gorakshya Rajya Laxmi, was said to have died from smallpox, but that he believed this was 'not strictly correct' as he understood she was pregnant from the late Raja and that the immediate cause was a premature birth caused by 'anxiety and cares at the late events'. ${ }^{123} \mathrm{He}$ added in brackets that 'it was always understood that she had had the smallpox in her youth' and would therefore be immune to the disease.

As a result of her death, Lalita Tripura Sundari, who was the queen grandmother of the new king and previously regent from 1806 until Girvana attained majority, again took over the role. She was also Bhimsen's niece. ${ }^{124}$ Speculation of foul play circulated among different groups at the court after Girvana's death. After 1816, Bhimsen's position as chief minister was more secure than before the war, but his control of the administration weakened after 1831, when the king attained majority, and in 1832 the former regent died. In 1837 Bhimsen was accused of being responsible for the poisoning of the young son of the king who had died suddenly. ${ }^{125}$ Although pardoned, the charge was revived in 1839 with some of the evidence used against him being testimonies that in 1816 he had poisoned both the king and queen. ${ }^{126} \mathrm{He}$ died in 1839 several days after an attempted suicide.

\section{Looking forward: From 1816 to the Global Smallpox-Eradication Programme}

The study of disease, medicine and public health in Nepal to date has been conceived largely in terms of development and anthropological perspectives, but this article has emphasised the value of in-depth historical study. ${ }^{127}$ It has provided an opportunity to look at a little known local context and, as Bhattacharya argues 'reclaim the historical experiences of small national entities'. ${ }^{128}$ In locating the introduction of vaccination in the events of 1816, the British archive adds an important new element to Nepal's history of smallpox. It clearly documents the motives, ideas and actions of Gardner in Nepal and the authorities in Fort William. Vaccination was a practical and humanitarian gesture, a

\footnotetext{
120 Gardner to Adam, 18 November. IOR/R/5/38.

121 Gardner to Adam, 20 November. IOR/R/5/38. This was the news referred to by Shrestha at the beginning of this article and in other accounts.

122 Stiller, op. cit. (note 27), 252.

123 Gardner to Adam, 17 December. IOR/R/5/38.

124 Ibid.

125 Stiller, op. cit. (note 27), 276.

126 Ibid., 282-3.

127 See, for example, Ian Harper, Development and Public Health in the Himalaya: Reflections on Healing in Contemporary Nepal (London and New York: Routledge, 2014). For an overview, however, of the historical development of Nepal's health services, see Hemang Dixit, Nepal's Quest for Health, 4th edn (Kathmandu: Educational Publishing House, 2014).

${ }^{128}$ Bhattacharya, op. cit. (note 13), 461.
} 
public health technology, but the British also saw it as a diplomatic strategy to improve their relations with the government of Nepal. Smallpox and vaccination in Nepal were topics of political significance to Britain and so appeared in its archive. ${ }^{129}$ In foregrounding Nepal, however, this article also contributes to broader discussions about the history of disease and public health campaigns. The Nepalese request indicated first that they knew about vaccination, but their control of how, where and to whom vaccination took place demonstrated how another government within the British colonial sphere of influence could operate on its own terms and with its own agendas and so place limits and boundaries on the British. Also, despite their vaccination request, the Nepalese did not share the British goals of a systematic process of setting up institutions and infrastructure and ongoing programmes. Implementing vaccination was far from being just a straightforward transfer of a technology.

To what extent the Nepalese perceived this introduction of vaccination as a public health intervention is questionable. Smallpox vaccination campaigns in the late eighteenth and nineteenth centuries are often seen in terms of early involvement of the state in a large population-based medical intervention. Although there are no statistical data for Nepal, vaccination in 1816 appeared to be accepted in the Kathmandu Valley both by leading families and also the general population. Despite British hopes, however, the provision of vaccination in the Kathmandu Valley was not the start of the wider expansion of the practice throughout the country. Even if the Nepalese government had wanted to establish a wider service in 1816 - which it gave no indication of - it would have faced enormous geographical, communication and infrastructural challenges.

After 1816 we know little about vaccination or smallpox in Nepal except for some scattered references to the ongoing presence of the disease and responses such as the continuing acceptance of variolation and offerings to the goddess. Relations between the British Residency and the government of Nepal were stable, with the British mostly adopting a policy of non-interference in Nepalese affairs. ${ }^{130}$ Oldfield's more familiar description of the prime minister Jang Bahadur's use of the Residency's medical staff and access to vaccine from India for vaccinating Nepal's elite illustrates his support for the practice, but Oldfield did not mention establishing a state service for the people. ${ }^{131}$ Insufficient vaccination or variolation no doubt contributed to the periodic smallpox epidemics that were a feature of the epidemiology of smallpox in Nepal. Other people could also receive vaccination from the Residency; in 1887 Tibetans are mentioned. ${ }^{132}$ By this time the Nepalese government was beginning to introduce some limited 'modern' medical services with the building of the first, mostly small, hospitals. ${ }^{133}$ 'Vaccination is not compulsory,' wrote Perceval Landon in the early twentieth century, 'but it is free to those who choose to avail themselves of this protection. ${ }^{134}$ The overwhelming majority of

\footnotetext{
${ }^{129}$ After the king's death on 20 November the Resident's letters did not refer to vaccination or any extension of activities. The Company file about the introduction of vaccination into Nepal also ceased and the documents were forwarded to London. They are to be found in the Company's political files, attesting to their significance in the political environment of the time.

130 The Residency of Hodgson (1833-43) was an exception. The ongoing supply of troops for the army became a key aspect of Britain's relationship with Nepal. See Asad Husain, British India's Relations with the Kingdom of Nepal 1857-1947: A Diplomatic History of Nepal (London: George Allen and Unwin, 1970).

131 Oldfield, op. cit. (note 4), 253-4.

132 G.H.D. Gimlette, Nepal and the Nepalese (London: H.F. \& G. Witherby, 1928), 155

${ }^{133}$ Babu Ram Marasini, 'Health and Hospital Development in Nepal: Past and Present', Journal of Nepal Medical Association, 42 (2003), 306-11; Dixit, op. cit. (note 127).

134 Perceval Landon, Nepal, (New Delhi: Asian Educational Services, 1993 [1928]), Vol. 2, 184.
} 
the population, however, lived in rural areas and would have been unable to access it. ${ }^{135}$ In practice, only in the changing political and social environment of Nepal in the 1950s did vaccination, along with other services such as education, begin to become more widely available throughout the country. Written and oral accounts of people's experiences with smallpox and vaccination during the 1950s and 1960s emphasise the country's lack of health services, whether state or private, and few medical practitioners or other options for vaccination throughout the country. Like much of the South Asian region, smallpox remained endemic and epidemic and much feared; the earlier practice of variolation, not surprisingly, continued.

The events in 1816 are instructive not only for what they tell us about smallpox in Nepal at the time, but also how they can help interpret events in Nepal a century and a half later and ask questions of the global eradication programme. Vaccination is a public health intervention, but its introduction into Nepal in 1816 clearly cannot be separated from the political environment of the time, internally within Nepal and externally with the state's relationship with the British in India. The history of the global smallpox-eradication programme has been written largely from a public health perspective, but more recently scholars have directed attention to considering, for example, the influence of the global power environment in the era of Cold War politics. ${ }^{136}$

As in 1816, implementing the new vaccination programme cannot be separated from the environment of the time, but the continuities between the two periods are also extremely important. Vaccination was politically desirable because of the need to help legitimise the new government after the return to a monarchy in 1951. It expanded its commitment to building infrastructure and providing services to help the wider population and not just the elite. The incentive of financial assistance from the WHO, USA, India, China, the Soviet Union and other countries provided opportunities to overcome the challenges of the country's limited resources in achieving its aims, but it was also the beginning of Nepal's troubled period of welcoming foreign aid. Agencies and organisations in the new era of international aid and development began to want to work in Nepal, but when the government requested outside assistance to help implement its plans, it also expected to be in control of what happened within its borders. While some factors such as the challenges presented by Nepal's diverse geography were not unexpected, Eugene Mihaly, in the first book on foreign aid in Nepal, found that plans had conceptual flaws as outsiders seriously underestimated the difficulties of working in Nepal. ${ }^{137}$ Most countries and agencies struggled and failed to meet their goals. As in 1816, Nepal's structures and resources were ill equipped for the challenges of national development set out in King Tribhuvan's Social Manifesto. ${ }^{138}$ With a population of nearly 8.5 million people, Nepal had just three hundred graduates and 1251 high-school students. ${ }^{139}$ Such statistics set the scene for the challenges of smallpox control and eradication initiatives.

\footnotetext{
${ }^{135}$ Raj, Aryal and Mishra, op. cit. (note 43). These small institutions were often situated where there were leading government officials.

${ }^{136}$ Erez Manela, 'A Pox on Your Narrative: Writing Disease Control into Cold War History', Diplomatic History, 34, 2 (2010), 299-323.

${ }^{137}$ Eugene Bramer Mihaly, Foreign Aid and Politics in Nepal: A Case Study, 2nd edn (Lalitpur, Nepal: Himal Books, 2002 [1965]), 204-7.

${ }^{138}$ Ludwig F. Stiller and Ram Prakash Yadav, Planning for People ([Kathmandu], Nepal: Human Resources Development Research Center, 1993).

139 Ibid., 22.
} 
In 1966, in line with the World Health Assembly decision to develop a global smallpoxeradication strategy, the government of Nepal began discussions with the WHO to continue their existing collaboration and move national efforts from control to eradication, signing an agreement in 1967 to establish a joint intensified programme. ${ }^{140}$ Activities expanded in Nepal as well as globally; but by the end of 1972 Nepal was one of only six countries where smallpox was still present. ${ }^{141}$ The last case of smallpox in Nepal, however, was in 1975, and eradication was declared achieved in 1977. The official verdict was that ultimately Nepal had a 'well-executed' programme. ${ }^{142}$ Significantly Nepal also appears as a one-page box inset at the end of the chapter about India in Donald Henderson's memoirs. ${ }^{143}$ Henderson, who had led the WHO global eradication programme, acknowledges reasonably that their main concern was India; he highlights, however, Nepal's 'unique program' after 1971 and - resonating with the situation in 1816 - the introduction of mass vaccination during a limited period each year while retaining the global focus of surveillance and containment. 'It was a new and surprisingly effective tactic in the eradication program.' Nepal's smallpox story had become part of the global history of smallpox.

Although Randall Packard has suggested that success with smallpox was due more to the nature of the pathogen, he discusses how the global smallpox-eradication programme was more flexible in its implementation than its predecessor - malaria. ${ }^{144}$ Much of the eventual success in Nepal with smallpox was due to the way that the small number of external personnel worked closely with national project staff and crucially to how the programme adapted to Nepalese conditions, making vaccine and vaccination available and accessible. While not inferring that there are 'lessons to be learned' from 1816, the events and wider context surrounding the death of the king and the introduction of vaccination shed light on the situation and challenges in Nepal facing the eradication team in the 1960s. Linking 1816 to the ultimately successful global eradication programme 150 years later reminds us of the need to think longer term as to why policies and programmes may or may not work as planned. Factors such as geography, politics, beliefs and practices, limited infrastructure, vaccine and logistics - many of which were important in 1816 resurfaced. This suggests that more broadly we ought not only to learn from looking at an immediate local context but that in the planning, policy making and implementation of mass programmes we should also give due consideration to the influence of systems, structures, attitudes and practices over longer periods. In the case of smallpox in Nepal, eradication success was deeply influenced by local physical and human environments that had developed over time.

\footnotetext{
${ }^{140}$ Shrestha, Robinson and Friedman, op. cit. (note 30), 17. In 1962 a joint Nepal Government/WHO smallpoxcontrol pilot project began in the Kathmandu Valley.

${ }^{141}$ Hopkins, op. cit. (note 3), 305. Four of these were in Asia and two in Africa.

142 Fenner et al. op. cit. (note 30), 715.

143 D.A. Henderson, Smallpox: The Death of a Disease: The Inside Story of Eradicating a Worldwide Killer (New York: Prometheus Books, 2009), 185.

${ }^{144}$ Packard, op. cit. (note 7).
} 